\title{
Polysèmes
}

Revue d'études intertextuelles et intermédiales

\section{The Genetic Parcours of a Literature of Trauma in Marie-Claire Blais's Literary Production}

From Painted Portraits to Photographic Ekphraseis: an Intimate Reaction to the Vietnam War

Julie LeBlanc

\section{OpenEdition}

Journals

Electronic version

URL: http://journals.openedition.org/polysemes/3408

DOI: $10.4000 /$ polysemes.3408

ISSN: 2496-4212

Publisher

SAIT

Electronic reference

Julie LeBlanc, «The Genetic Parcours of a Literature of Trauma in Marie-Claire Blais's Literary

Production », Polysèmes [Online], 19 | 2018, Online since 30 June 2018, connection on 30 April 2019

URL : http://journals.openedition.org/polysemes/3408; DOI : 10.4000/polysemes.3408

This text was automatically generated on 30 April 2019.

Polysèmes 


\section{The Genetic Parcours of a Literature of Trauma in Marie-Claire Blais's Literary Production}

From Painted Portraits to Photographic Ekphraseis: an Intimate Reaction to the Vietnam War

\section{Julie LeBlanc}

Ces jeunes manifestants ont vu ou ont éprouvé le malaise de grandir parmi ces images de ce qu'on appelle alors la guerre du Vietnam, car les

férocités de cette guerre leur furent quotidiennement transmises, ils ont été choqués, traumatisés par ces images [...] des exécutions dans les rues... (Blais 2012, 50-51)

Individuals who experience wars, disasters, accidents or other extreme "stressor" events seem to produce certain identifiable somatic and psycho-somatic disturbances. Aside from a myriad of physical symptoms, trauma disrupts memory, and therefore identity, in peculiar ways.

(Luckhurst 1)

Many theorists, critics and writers (Adams, Butler, Egan, Gilmore, Heddon, Hirsch, Kadar, Lejeune, Perrault, Simonet-Tenant, Olney, Rugg, Smith, Watson, etc.) have proposed that the $20^{\text {th }}$ and $21^{\text {st }}$ centuries should be treated as ages of "bearing witness or testifying" (Heddon). This is perhaps best epitomized by the proliferation of autobiographical narratives published in the past century and the rise of extremely diverse theories for the study of life narratives (structuralist, historical, cultural, visual, feminist, genetic, and performative). What Suzanna Egan calls "testimonial culture" (Egan and Helms ix) ${ }^{1}$ is part of and related to a more general memory boom, itself indebted to the "transformation of the personal into the political". My article will be focused on Marie-Claire Blais's political 
testimonials, more importantly the textual representations of wars and the social and political crisis which they gave rise to during the $20^{\text {th }}$ and $21^{\text {st }}$ centuries. Through her textual and pictorial reflections on war found in her unpublished illustrated notebooks/ diaries (1965-1970), novel (David Sterne, 1967), short story (“Le Tourment", 1988), ${ }^{2}$ essays ( Parcours d'un écrivain, 1993; Passages américains, 2012) and autobiographical narrative ( Des rencontres humaines, 2002), ${ }^{3}$ which span more than five decades, Blais has become a performative witness to past tragic sociopolitical events which have haunted her since the 1960s: World War II, the Holocaust, the Vietnam War, the murder of American political figures (J.F. Kennedy, Dr. Martin Luther King and Robert Kennedy), etc. My study is situated at the intersection of several major trends in the field of genetic criticism (study of manuscripts), theories of autobiography, word and image studies, and various literary theories. Using an interdisciplinary perspective, my research is focused on studying the textual and visual strategies exploited by Blais to narrate her subjective experiences and to illustrate and perform her personal and collective memories dominated by a series of political crises.

The variety of texts (notebooks, diaries, autobiographical narratives, short stories, novel, essays) ${ }^{4}$ as well as the drawings and paintings that she produced over the past six decades allow us to trace an evolution in Blais's textual and visual representations of various wars and the national/international crisis which they gave rise to. Blais's descriptions of the inexhaustible variety of human experiences is motivated by her irrepressible impulse to explore the various forms of personal and social crisis that the devastating effects of wars have given rise to since World War II. The textual and painted images generated by Blais in her published and unpublished texts all relate to realities of the world, more specifically to social, cultural and political contexts dominated by war.

The focus of this study is to explore the relationships that exist between Marie-Claire Blais's unpublished illustrated notebooks written during the 1960s and her more recently published essay (Passages américains, 2012) as they are significant works in this development of a literature of crisis and trauma where racism, war, violence, American politics and the Vietnam War reappear as dominant figures examined by Blais for almost decades. Roger Luckhurt's definition of trauma and Croft's concept of a "crisis cycle" are extremely useful in my analysis of the discursive project that Blais embarked upon in the 1960s when she resided in the United States. Blais revisits the traumatic events of the Vietnam War and the violent assassination of political figures in her more recently published essays and autobiographical narratives, Écrire des relations humaines, and more importantly in Passages américains which references many iconic photographic images of the violent deaths of political figures (President John F. Kennedy and Dr. Martin Luther King), more notably the assassination of Senator Robert Kennedy. He is at the core of the initial essay published in Passages américains and his violent death is the subject of detailed photographic ekphraseis ("to describe exhaustively an object or existing artwork as vividly as possible in order to bring it before the eye of the listener", Robillard and Jongeneel 1). The representation and commentary on the Vietnam crisis and the traumatic outcome of this tragic war on Americans, the Vietnamese and on Blais herself who was residing in the United States during these tumultuous years is an expanded and visual narrative of previous discursive projects. It is her unpublished illustrated notebooks, where the traumatic events of the war and its aftermath were first vividly exploited. Genetically speaking these diaries serve as an "avant-texte" to this cycle of texts focussed on repeating, through various textual and pictorial devices, her strong 
political convictions. In other words, all of her texts referenced in this paper find themselves genetically related to her unpublished notebooks. It is within these illustrated diaries that the immense isotopic network began and that her visceral description of her reaction to the Vietnam War was born. The pictorial dimension of her notebooks, replete with painted and drawn portraits, is also fundamental to the vivid descriptions, figures of ekphrasis and more importantly the photographic portraits described in her last published text. ${ }^{5}$

\section{Excerpts from M-C Blais's unpublished and illustrated notebooks: Fonds Marie-Claire Blais, National Library and Archives Canada}

Jeudi 7 juillet 1966

Il y a des jours où l'on ne veut penser à rien de grave, rien de sérieux, où l'on veut s' abandonner à l'instant comme s'il était éternel. C'est l'été peut-être qui fait cela, mais combien on a soif, pourtant, de très loin - de cette discipline, de cette rigueur qui sauveraient tous les instants que l'on a mal vécus. Et pourtant, dans le journal, il y a là un enfant à Hanoï victime d'un raid - et puis, on ne sait pourquoi - rien ne semble plus vrai. À nouveau, c'est l'absurde, la destruction de la vie qui entre en vous.

Ce soir inquiétude folle apprenant à la TV que l'on avait encore bombardé Hanoï Voilà le présent, l'avenir ! À quoi sert la lutte !

The images referenced in her notebooks ("dans le journal, il y a là un enfant à Hanoï victime d'un raid [...] c'est la destruction de la vie [...] [on apprend] à la TV que l'on avait encore bombardé Hanoï") are then reintroduced in many of her fictional, autobiographical narratives and essays published during the next five decades. Blais's narratives generate a spectrum of closely related themes, which confer a semantic continuity to the literary production analysed in my paper. One can actually retrace the evolution of her narrative strands, the creation of motifs, the diegetic organization of her narratives and the construction of a discourse aimed at denouncing the brutality of the Vietnam War. My hypothesis is that Blais's attention to visual representations, painted portraits in her unpublished notebooks and photographic ekphrasis in her more recently published autobiographical essays, is commensurate with her lifelong ambition to extend the word-bound limits. The relevance of the word and image relations is essential to my argument, for it strikes at the very nature of Blais's writing style. I wish to read Blais's unpublished illustrated notebooks, her fiction and autobiographical essays as part of a visual system that develops cognitive patterns to create synergism between verbal and visual systems, where painted portraits, photographic images and vivid descriptive passages are exploited to represent the traumatic effects of the Vietnam War on American and foreign soil. The murder of prominent American politicians, the death of thousands of American soldiers and innocent Vietnamese are all referenced in this series of texts. Thus, genealogy is a crucial part of the construction of meta-narratives in Blais's literary and politically charged textual and pictorial representations of the crisis which has obsessed her since the 1960s: the Vietnam War, the longest war in American history, which killed 50,000 Americans in action, wounded 30,000, cost $\$ 111$ billion dollars, and covered the mandates of three United States presidents. For Blais, as with many historians, wars are political constructs that unavoidably give rise to crisis situations, traumatic deaths, destruction of social-political-cultural infrastructures: conflicting 
social, religious and political values are often at the centre of violent acts of war. As Croft reminds us a crisis is itself "constructed in and through social interaction". It is given meaning through social processes, through a decisive intervention, which gives meaning to the situation. As we know, there are no objective ontological criteria that a trauma resulting from a crisis must fulfil: "a crisis is one when it permeates discourse and creates new understandings" (Croft 5). What I have chosen to call the genetic "parcours" of a literature of trauma in this selection of texts written by Blais over four decades permeates her unpublished illustrated notebooks and more importantly Passages américains which will be the focus of my study.

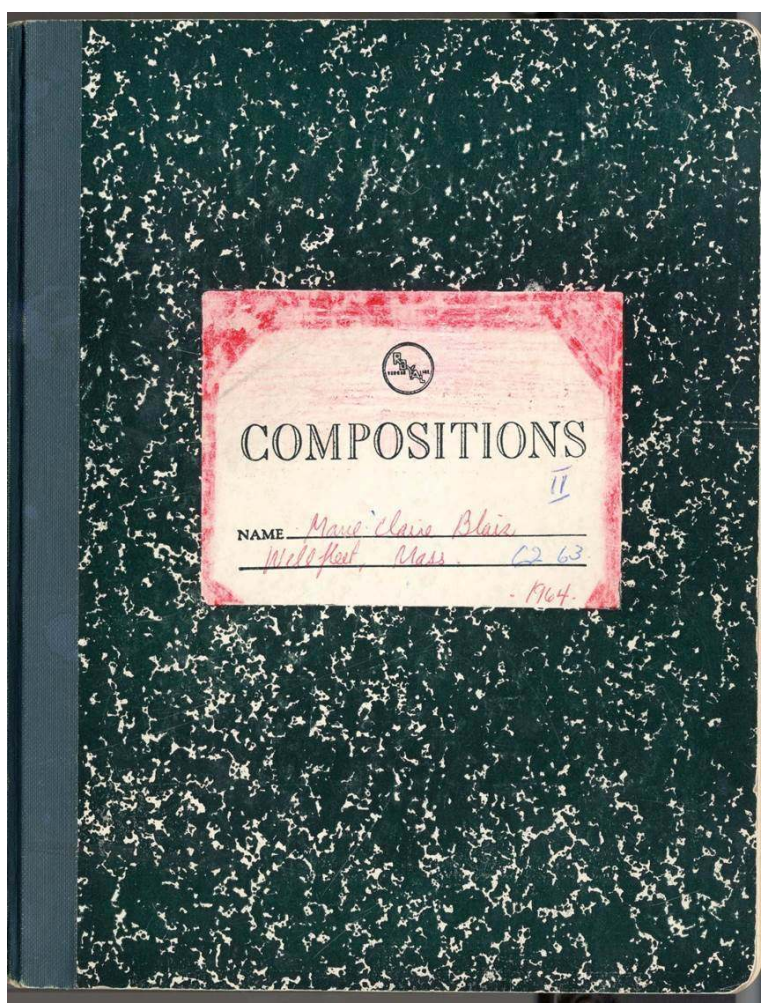

Fig. 1: Marie-Claire Blais's unpublished illustrated notebooks, Fonds Marie-Claire Blais, National Library and Archives Canada, Ottawa

5 It is in her unpublished handwritten notebooks that we first encounter Blais's reactions to the traumatic events of the Vietnam War. Blais began to write in her notebooks in 1963 after leaving her native Québec to live in the United States after receiving a Guggenheim Fellowship. Coincidently, President John F. Kennedy was murdered that same year. These various excerpts that I have chosen to reference are organized to stress her obsession with the Vietnam War, to draw attention to the introspective nature of her unpublished diaries and display the rich genetic qualities of these notebooks. The genetic dimension of Blais's unpublished notebooks is of particular interest as they present extremely valuable information in respect to the genesis of her literary production and the evolution of her ideological convictions. Adopting the perspective of many precursors of genetic criticism, I am interested in Blais's unpublished notebooks as a valuable tool to understand her literary production in its making. These notebooks allow for the reconstruction of the intellectual, linguistic and cultural processes that were involved in the genesis of her literary production. Apart from the wealth of genetic information introduced throughout these notebooks, they are also dominated by subjective introspective comments. They are also saturated with painted portraits that accompany Blais in her description ${ }^{6}$ of the crisis 
of the Vietnam War and the writing of David Sterne, a violent novel conceived at the crux of this war.

Excerpt taken from Blais's unpublished notebooks: their genetic qualities

David Sterne [...] le cauchemar de ce livre [...]. C'est direct et cruel, simple et barbare comme le personnage. Il est vrai que tout idéal doit être détruit, tout héros renié, tout maître trahi, si l'on veut vivre [...]. Je rencontre un homme dans la rue à qui je parle des horreurs de la guerre du Vietnam « I am writing a diary, called the 50 days of the Vietnam War » - lui aussi est d'accord que cette guerre est horrible, inutile [...].

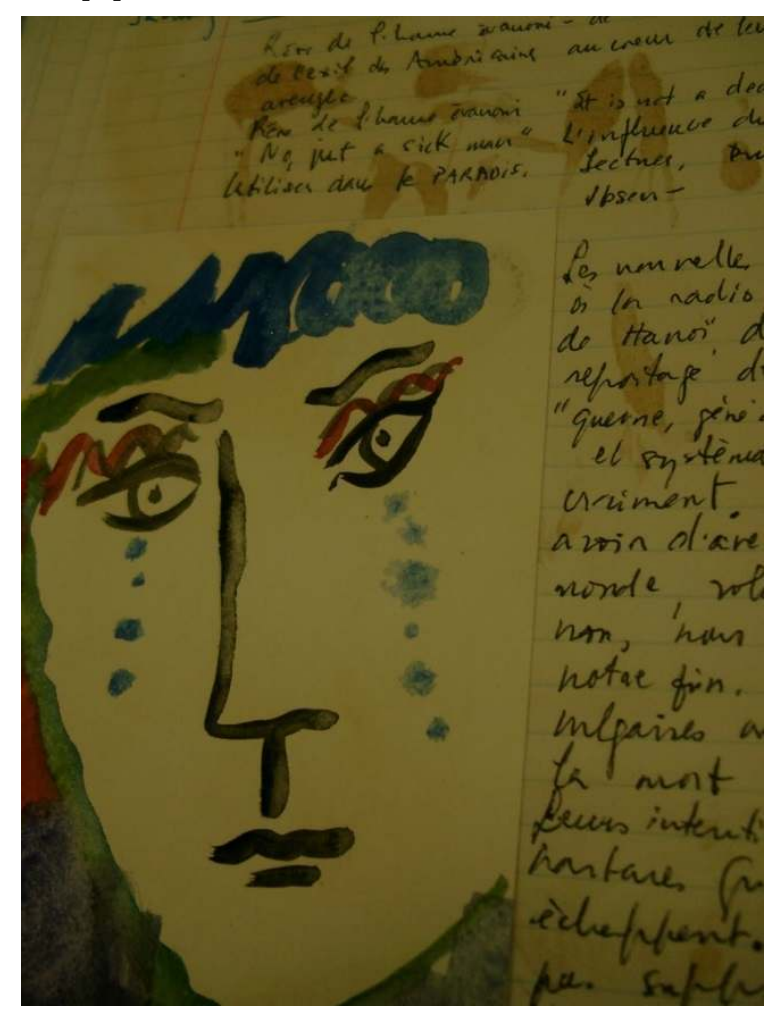

Fig. 2: Excerpt from Marie-Claire Blais's unpublished notebooks, Fonds Marie-Claire Blais, National Library and Archives Canada, Ottawa

7 This fragment is my transcription of the diary entry which accompanies this painted portrait:

Rêve de l'homme évanoui - de la société américaine, de l'exil des Américains au cœur de leur monde aveugle. "It is not a dead man? " « No just a sick man ». L'influence du mensonge dans le paradis. Les nouvelles ce matin à la radio évacuation de Hanoï [...] un génocide planifié et systématique non vraiment. Il ne peut y avoir d'avenir pour le monde, volontairement ou non, nous marchons vers notre fin. Les têtes malsaines ont décidé de la mort de nous tous. Leurs intentions sont si barbares qu'elles nous échappent. On ne peut pas supporter la tuerie continuelle. Si l'autre est assassin, toute la conscience du monde en souffre.

8 Many of the portraits introduced in her notebooks are sombre pictorial images, which at times entertain a very close relationship with the anxiety and sorrow that dominate her diary entries. This visual medium which punctuates her unpublished notebooks are another means to externalize what words cannot express. The fascination for portraiture also dominates Passages américains which will be the focus of the latter part of this article. Portraiture (textual and iconographic), the Vietnam War and photographic ekphrasis have dominated her writing for decades. 


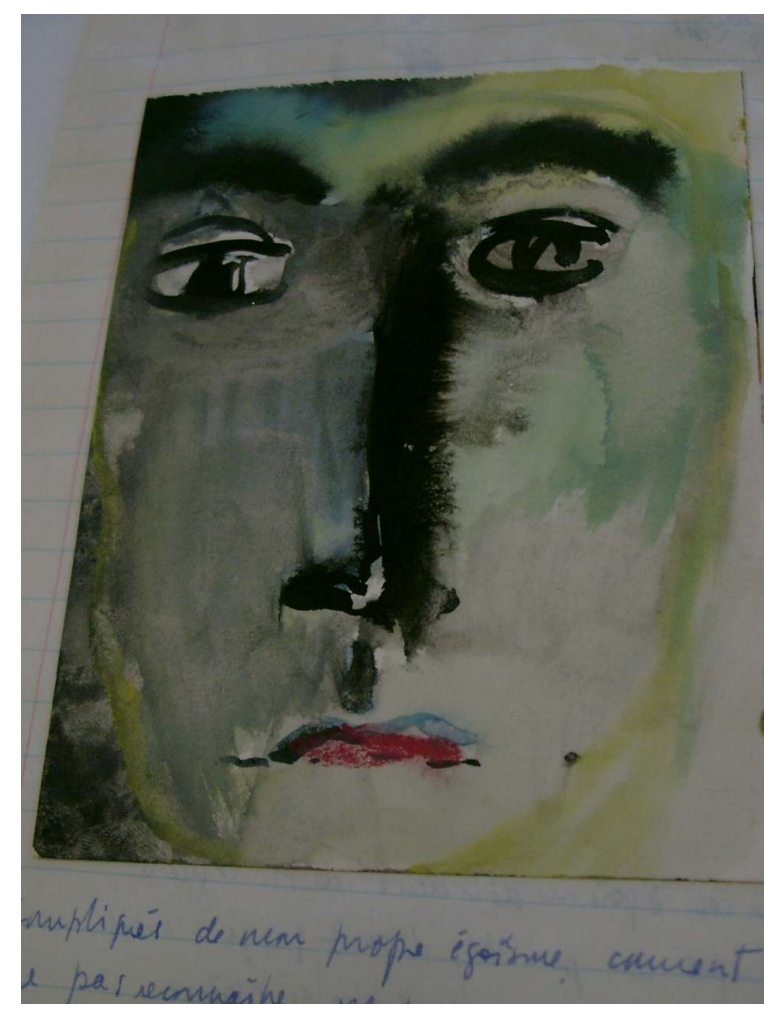

Fig. 3: Excerpt from Marie-Claire Blais's unpublished notebooks, Fonds Marie-Claire Blais, National Library and Archives Canada, Ottawa

9 Although Blais's numerous notebooks are punctuated with abstract images executed with pastels, almost all of the portraits painted and drawn within her notebooks were executed in the late 1960s when Blais was consumed by the Vietnam War and the writing of David Sterne. The manuscripts reveal to what extent these historical and political events have influenced her life as a writer and a citizen of the world. The memory of past wars (World War II, the Holocaust, the anti-Semitic agenda of the Nazis, the Vietnam and Korean Wars) and, more recently, Blais's references to wars in Indochina and the Middle East, allow her to unite different historical and political contexts, to engage in a transatlantic voyage where American war efforts of the 1960s are meshed with the German occupancy of the 1940s. This is connected to recent wars and crimes against humanity in Asia, China, Iran and Iraq. It is through this transposition (or transference) that our sense of the historical complexity of these wars grows and that Blais is able to cross the Atlantic, extend her spatial-temporal boundaries, allude to numerous other countries, eras, cultures, ideological practices and international crises.

The culmination of decades of writing about the Vietnam War and its traumatic effect on American politics and on Vietnamese culture comes to a halt, at least temporarily, with the publication of her essay Passages américains. Between her unpublished notebooks which represent the first descriptions of this gratuitous war (1960s) and this beautifully written political testimonial (Passages américains), the word and image dialectic takes on a new structure with photographic ekphrasis replacing painted portraits. In Blais's last autobiographical essay published in 2012 we find the crisis of the Vietnam War at the forefront of this text dedicated to all of the political, historical, cultural topics that have been referenced in Blais's unpublished notebooks, manuscripts, autobiographical narratives, novel and short stories referenced in the previous page. 


\section{Passages américains and the use of photographic ekphrasis: the slaying of Robert F. Kennedy}

11 Although Blais's description of the tragic events of the Vietnam War and of the senseless death of three prominent American political figures during this conflict, along with her support of anti-war movements, are referenced throughout her unpublished illustrated notebooks, autobiographical narratives (Parcours d'un écrivain: notes américaines; Écrire des relations humaines) and short stories ("Le Tourment"), it is the detailed description of an iconic photograph of Robert Kennedy taken by Time Magazine photographer Bill Eppridge ${ }^{7}$ who had followed Kennedy's campaign that serves as a introduction to Passages américains. This first long essay dedicated to Robert Kennedy ("Lamentation pour un sénateur foudroyé") is a powerful commentary on violence, racism, the traumatic effects that the Vietnam War had on American culture and politics.

Using figures of ekphrasis ("the verbal representation of a visual representation") 8 and more importantly of a photographic ekphrasis (a detailed description of Eppridge's iconic photograph of Robert Kennedy minutes after he was shot, resting in the arms of Juan Romero, the young busboy of the Ambassador Hotel), Blais invites us to ponder the poetic and visually descriptive quality of her emotionally and politically charged textual reproduction of this devastating photograph. ${ }^{9}$ As A. Castro so astutely suggests, the study of photographic ekphrasis contributes to the "problematization of the realistic readings of historical and biographical accounts [...]" ${ }^{10}$ The descriptions of photographs as the ones found in Blais's essay act as a substitute for an absent referent (Roland Barthes's "ça a été"), a "re-semantization of the referent" (Castro 3) (which we find in both Blais's and Eppridge's description of the iconic photos of Kennedy's death), as a means to arouse new emotions and re-document, through a different medium (words), this tragic event.

13 As Susan Sontag reminds us, there is something predatory in the act of taking a picture. To photograph people, explains Sontag, "is to violate them, by having knowledge of them they can never have; it turns people into objects that can be symbolically possessed: just as the camera is a sublimation of the gun, to photograph someone is a sublimated murder -a soft murder, appropriate to a sad, frightened time" (Sontag 14-15). Sontag's perspective is obviously very pertinent to any analysis of a photograph taken in the context in which Robert Kennedy's picture was taken, minutes after he was shot and critically injured. When one reads Eppridge's own account of the events, which I believe stems partially from his description of his own series of photographic images taken of Robert Kennedy seconds after his vicious attack (“Bobby's eyes were open and he was trying to speak. He was clenching and unclenching his right fist [...] The busboy looked up [...] for someone to help as I shot the third frame. By the fourth frame. People started crowding in", 137), one realizes that these two descriptions (Blais's and Eppridge's) can both be treated as photographic ekphrasis: one is offered to us by a writer and the other by the witness/photographer of this traumatic event. These two distinctive photographic ekphraseis give rise to a sort of effect of mise en abyme, of dédoublement and recoupement which serves to accentuate the tragedy of this senseless death while emphasizing the subjective nature of these three different representations of the same tragedy: Eppridge's iconographic representation first published in Life Magazine in 1968, Blais's detailed description introduced in her essay and finally Eppridge's personal description of his iconic photographic images introduced in A Time it was: Bobby Kennedy in the Sixties. This 
violent image of Kennedy's murder was not only deeply traumatic for the individuals present, but for viewers who would eventually gain access to this tragic incident through the dissemination of these images in various mediums: television, magazines, newspapers and books. Arheim reminds us that the photographer takes a "hunting pride in capturing the spontaneity of life without leaving traces of his presence" (Arheim 151). These thoughts echo Sontag's analysis of photographic sublimation and more notably of Eppridge's own description of the moment he took his photograph of Robert Kennedy, reproduced in A Time it Was: Bobby Kennedy in the Sixties published in 2008. Roland Barthes's numerous comments on the relationship between death and photography eloquently reiterates many parallels that have been made between these two phenomena: "Ultimately, what I am seeking in the photograph [...] is Death [...] the only thing I tolerate [...] is the sound of the camera. For me, the Photographer's organ is not his eye (which terrifies me) but his finger [...]" (Barthes 1991, 43). As we ponder Eppridge's description of what he witnessed and what he re-witnessed through his visualization of his own photographic images, one notices that unlike Blais, Eppridge's goal is to offer a personal context to these horrific images, to present in a mechanical manner the photographic performance and to describe many decades later and with some emotional distance (conscious or not) the event and the images taken to represent this tragic incident:

It was clearly eight shots

[...]. I remembered saying to myself as soon as I saw the senator on the floor, "OK. You've had ten years of training for a moment like this... now go to work."

We found the Senator-fallen bleeding-being held by a hotel busboy that was the last to shake his hand. Bobby's eyes were open and he was trying to speak. He was clenching and unclenching his right fist. [...]

The busboy looked up, begging for someone to help as I shot the third frame. By the fourth frame, people started crowding in.

Very deliberately, I helped hold back the crowd. At the same time, however, and with a wide-angle lens on my camera, I began taking pictures from the hip. Nobody noticed me.

Those twenty minutes in the kitchen seemed like an eternity, but I had shot less than two rolls of film. (Eppridge 137)

His description does not measure up to the emotional and vivid rendition that Blais presents in her essay, but the predatory nature of his endeavour, the photographic shoot of this sad and frightened time, is well accounted for in his description of the photograph and the context in which it was taken. Eppridge witnessed this brutal slaying decades before their description in his book. Fragments of the passages dedicated to this tragic event seem to function like photographic ekphrasis: it is as if parts of his descriptions were inspired by the iconic photographic images he took of the incident. What clearly distinguishes Eppridge's and Blais's descriptions is the fact that Eppridge offers specificities about the medium of photography and the processing details adhered to in the production of these photographs ("I went to Kennedy's feet because the lighting from Jimmy's movie light was better [...]. I made two frames with my camera [...]. I shot the third frame. By the fourth frame, people started crowding in [...]. I had shot less than two rolls of film", 137), instruments of production and the context in which the photos were taken ("When the film arrived J. Eyerman (another staff photographer from Life) asked for my film processing instructions. He knew that I tended to underexpose my film and it was his expertise in the darkroom that preserved the image of Bobby on the floor with the busboy", 151). It is the technicality of this description which partly deprives it from 
the subjective sentimentality which is so powerful in Blais's photographic ekphrasis: “Tout nous est révélé dans ce dernier regard que Robert Kennedy posa sur le monde, de son ultime détresse déchirant ce brouillard où se débattent, toutes courbées vers lui, ces ombres [...] d'êtres aimés. [...]. Ce busboy [...] soutient le poids d'une tête d'où coule le sang, et ces gouttes de sang, dans la paume de celui qui joue ce rôle de sauveur avec vigilance" (Passages américains, 12-14). This affect-oriented ekphrasis and Blais's representation of this traumatic event is multi-dimensional as it introduces many different perspectives on this tragic moment. Blais's emotional rendition of the event based on her viewing of Eppridge's photo constitutes a form of re-witnessing of an historical event originally witnessed by Bill Eppridge and others present during the assassination attempt: Juan Romero, the busboy, holding Kennedy's head and looking into Eppridge's camera lense, was also the other primary witness to this brutal slaying. Many theorists referenced in this article (Heffernan, Cheeke, Robillard, Louvel) believe that in the strongest examples of ekphrasis, there is always therefore a sense of extension or enlargement, but one which brings with it a pressure to discriminate and differentiate between the two media (the photograph and its description in the form of an ekphrasis), and the experiences of two individuals: Eppridge's witnessing of the event, his photograph of what he witnessed and Blais's own visceral description of the event based on Eppridge's iconic photographs of this tragic event. In his study of poems about photographs Cheek explains that "photographs both are and are decidedly not true memorials [...] there is always potentially an excess of pathos in the photograph's moment, a sentimentality inherent to its calibration of loss" (Cheeke 147). The intelligibility of the photograph is no simple thing; photographs are texts inscribed in terms of what we may call photographic discourse, but this discourse, like any other, engages discourses beyond itself. The photographic text, like any other, is the site of a complex intertextuality, an overlapping series of previous texts taken for granted at a particular cultural and historical conjuncture. Blais's discourse on the Vietnam War conceived during the 1960s in her unpublished notebooks and revisited decades later in her autobiographical narratives and short stories entertains a complex intertextual and intratextual relationship with her last published essay (Passages américains) in 2012. There is obviously an intertextual relationship between Blais's essay dedicated to Robert Kennedy, Eppridge's photographs of his slaying and the description that Eppridge offers us in his book, A Time it Was: Robert Kennedy in the Sixties. Like many forms of ekphrasis what is at stake in Blais's and Eppridge's photographic ekphraseis is the status of space and time in their representational/descriptive attempts at making Robert Kennedy's photograph into the "verbal equivalent of a plastic art object" (Cheeke 2).

Blais's attempt to translate photographic images into words does not end with her essay dedicated to Robert Kennedy and the violent images of his slaying. In this essay she calls upon other photographic ekphrases presenting the reader with other politically charged images. One soon realizes that Blais's photographic ekphrasis (the photograph of Robert Kennedy seconds after being shot), which takes up numerous pages of this emotional rendition of this tragic event, serves as a pretext to recreate the historical and cultural crisis that the senseless deaths of Robert Kennedy, Martin Luther King, and John F. Kennedy gave rise to. These photographic ekphrases referencing the photographic images of the violent slaying of John and Robert Kennedy (reproduced in numerous magazines, books and on television) and the image of a grief-stricken Mrs King attending her husband's funeral with her young daughter is also a strategy used to speak about her 
description of these deeply traumatic events and a means to introduce the barbaric nature of the Vietnam War and the Tet Offensive (1968) which occurred in the same political era as the murders of three prominent American politicians. Her description of these other iconic images used to express the trauma caused by these senseless murders leads her to the description of another well-known and award-winning photograph of a young Vietcong being executed in 1968 by a South Vietnamese general. This photograph entertains a strange relationship with a famous speech Robert Kennedy gave in February 1968, a few months before his own violent murder on June $5^{\text {th }} 1968$. This speech was one of his first actions, aimed at breaking away from President Johnson and his stance on the Vietnam War. ${ }^{11}$ The photograph that Eppridge would eventually take of Kennedy's shooting in June 1968 entertains a morose relationship with the photograph of this execution in February 1968.

Ces jeunes manifestants ont vu ou ont éprouvé le malaise de grandir parmi ces images de ce qu'on appelle alors la guerre du Vietnam, car les férocités de cette guerre leur furent quotidiennement transmises, ils ont été choqués, traumatisés par ces images de ce qu'on appelle alors l'Agonie de la Victoire, de la guerre du Vietnam, car les férocités de cette guerre leur furent quotidiennement transmises sur l'écran de la télévision familiale, le soir; ils ont vécu dans l'intimité de cette barbarie filmée, voyant chaque jour de jeunes soldats, souvent des jeunes gens à peine plus âgés qu'eux, courir sous les bombes, ou soutenant entre leurs bras un camarade au visage couvert de sang et de boue, ils ont été choqués, traumatisés par ces images du massacre de My Lai par le lieutenant William Calley qui en fut responsable, ils ont été scandalisés par l'offensive du Têt, et l'indécence des exécutions dans les rues... la froide exécution, à bout portant du revolver, par un général du Vietnam du Sud, d'un jeune homme vêtu d'une chemise à carreaux, soupçonné de trahison, le jeune homme, toujours debout, les mains liées derrière le dos, grimaçant devant la mort, affrontant son assassin, la tête levée, un homme tué sans procès... L'adolescent Viêt-Cong froidement exécuté par un vieux général à l'impassible profil vicieux devint le symbole de l'outrance meurtrière d'une guerre exerçant partout ses châtiments. (Passages américains, 50-51) ${ }^{12}$

In this long fragment dedicated to the description of two iconic photographs by awardwinning photographers, Blais references Eddie Adams's photograph of the Viet Cong suspect being executed by a Vietnamese General and also the My Lai massacre of March 16, 1968 when U.S Army troops headed by $1^{\text {st }}$ Lt. Calley Jr. (in an operation that was meant to locate the Viet Cong), destroyed the village of My Lai and killed hundreds of people including the elderly, women and children. With these last two images, the violence and murderous acts previously restricted to American soil with the slaying of John Kennedy, Robert Kennedy and Martin Luther King, now reference the brutal actions against Vietnamese by American soldiers as well as by Vietnamese military authorities. The tragedy underlying all of these slayings of political figures, the Vietnamese and the American soldiers are introduced to draw our attention to the gratuitous violence of war, racism and to other devastating outcomes of war. Although the references to the $21^{\text {st }}$ century are not very numerous, Blais does reference Obama, other wars and devastating crimes against humanity. She continues to stress that the lessons of the Vietnam crisis were not important enough to stop the involvement of the Americans in many other international and political crises or to stop the inception of numerous wars and acts of violence against humanity that have plagued the world and have given rise to the same types of atrocities and crimes committed during the Vietnam War. The Vietnam War described and revisited in Blais's numerous published and unpublished texts is at the core 
of what she describes in her last essay as a racist war, a ferocious, barbaric, indecent, traumatizing war:

Nous sommes en octobre 1967 [...] pour plusieurs de ces manifestants, cette guerre est raciste, et tous ne cessent d'être témoins chaque jour à la télévision, dans les journaux, des atrocités de cette guerre. (Et nous voici encore bien près des événements que nous vivons aujourd'hui, avec les guerres successives, et la même atrocité dans les crimes). [...] quand se perpétue encore aujourd'hui une semblable boucherie, en Iran, en Chine, tueries en Chine de centaines de jeunes gens, pour une minime vente de cannabis, pendaisons dans les rues, en Iran, de jeunes voleurs dont on voit les noires silhouettes accrochées à de gigantesques grues. (Passages américains, 50)

These historical and politically charged textual and iconic images (the execution of the young guerrilla, the My Lai Massacre, the descriptions of the pain and suffering of young American soldiers sent to Vietnam) are juxtaposed to more recent political, violent and inhumane crises: in Iran, China and other countries plagued by wars, violence and crimes against humanity. It is my opinion that Blais's texts form a cycle marked by trauma that came to an end, at least temporarily, with the publication of Passages américains in 2012. In other words, this last personal essay on the Vietnam War, is a clausular text, in which Blais intimately describes the devastating effects of the War, violence and racial discrimination. However, unlike her other texts, which preceded the publication of her most recent essay in 2012, she uses iconic photographic images in an attempt to vividly represent this political and cultural crisis. What all of these photographic ekphraseis have in common is the manner in which they present what Roland Barthes so astutely calls a detail, this visual element which pricks the viewer's attention. This punctum which touches us in certain photographs, this visual element which "rises of its own accord into affective consciousness" (Barthes 1991, 54), acts as a sort of supplement enhancing the spectators' viewing pleasure. The punctum functions somewhat like a figure of ekphrasis which also interferes with our linear reading of the text, it has the potential for presenting an excess of pathos, for giving rise to a moment of sentimentality, for disrupting the syntagmatic construction of the narrative within which it is inscribed: this is what Barthes so astutely calls the point or the sting that captivates, surprises, awakens feelings and fundamentally touches us sharply. Eppridge's iconic photographs, the descriptions he offers to his readers and Marie-Claire Blais's use of photographic ekphraseis are also fundamentally related to Barthes's studium. This general, cultural and civilized interest one has in a photograph corresponds to the photographer's (in this case to Eppridge's) images and the manner in which his iconic images of death "attract our studium" (Barthes 1985, 352).

\section{In conclusion}

Blais teaches us that images are not simply a different kind of sign: "they are fundamental elements of world making. Like language, they hold the world together with figures of knowledge that cannot be reduced to simple notions of representational artifice" (Ricci 15). For Blais questions of representation trace their linkages to issues of media, power, history, culture and ideology. What is at the crux of her unpublished notebooks and more recently published essay (Passages américains) is the question of representing traumatic events. The violent slaying of political figures during the 1960s, the victims (young American soldiers and innocent Vietnamese) of the Vietnam War are the main 
focus of her numerous texts (novel, short stories, autobiographical essays, unpublished diaries) produced in the past five decades. The traumatic stories recounted, the tragic unfolding of events, the victims of political regimes are persistently re-experienced and re-witnessed in Blais's narratives which at times call upon images (painted, drawn and photographed) in her presentation and representations of traumatic events which had political and deeply personal repercussions. The narrative strategies used in her reconstructions of human tragedies (opposing the victims of the Holocaust to the Nazi regime; the American soldiers involved in the Vietnam War to the conscientious objectors/Pacifists; the political regimes in power to the victims of violent inhumane tragedies), the socio-cultural messages that these representations convey in Blais's literary production (anti-war, anti-racist, anti-clerical; the gratuitous and violent nature of warfare), the manner in which they allow her to journey into other countries (the USA and Vietnam) and embrace other transatlantic historical tragedies (the Holocaust, German Occupations, World War II, wars in Iran and Iraq, international crimes against humanity, etc.) are all testimonials to Blais's remarkable talent to summon up vivid images of the violent and destructive nature of wars which cross oceans, cultures, military regimes and historical contexts. Her narratives generate a broad spectrum of themes, which confers a certain semantic continuity to the literary production analysed in my paper. One can actually retrace the evolution of her narrative strands, the genesis of her political convictions and that of her conceptualization of what constitutes a trauma. From this perspective, her novel David Sterne, her short story "Le Tourment", and her autobiographical essays, Notes américaines, Écrire des relations humaines and Passages américains are all genetically related to her unpublished and illustrated notebooks. It is in these unpublished diaries that the immense isotopic network began, that her visceral description of her reaction to the Vietnam War and the trauma that it gave rise to were exploited one last time in Passages américains. The pictorial dimension of her notebooks, saturated with painted and drawn portraits, is also fundamental to the vivid descriptions, figures of ekphrasis and more importantly photographic portraits used in her last published text, which not only references this iconic photo of Robert Kennedy but also portraits executed by Roy Lichtenstein and Louis Glanzman after his death and placed on the cover of Time Magazine: these are described by Blais in the last pages of her essay. As it was mentioned in the previous pages, what distinguishes her numerous other texts (notebooks, novels, short stories) which preceded her last essay published in 2012 is her references to other more recent political and cultural crises which have plagued the international community. I would like to end my text with an editorial, entitled "A Moral Crisis", published on September 3, 2015 in the Toronto Globe and Mail. It references the Syrian crisis and the tragic death of Aylan Kurdi with the photograph of the 5-year-old boy's body washed up on a beach in Bodrum. This editorial resonates with Blais and also with the actions of many photojournalists of the late 1960s covering through their lenses the crisis of the Vietnam War, the common attempts at denouncing the consequences of these senseless wars, allowing us to visualize and re-visualize the violence of this war and of many recent wars and crimes against humanity. 


\section{BIBLIOGRAPHY}

Angeletti, Norberto and Alberto Oliva. The Illustrated History of the World's Most Influential Magazine. New York: Rizzoli, 2010.

Arheim, Rudolf. “On the Nature of Photography”. Critical Inquiry 1.1 (September 1974): 149-161.

Barthes, Roland. Camera Lucida: Reflections on Photography. Trans. Richard Howard. New York: Hill and Wang, 1991.

Barthes, Roland. The Grain of the Voice: Interviews 1962-1980. London: Jonathan Cape, 1985.

Blais, Marie-Claire. Passages américains. Montréal: Boréal, 2012.

Blais, Marie-Claire. L'Exilé: nouvelles suivi de Les voyageurs sacrés. Montréal: Bibliothèque québécoise, 1992.

Blais, Marie-Claire. Exile and the Sacred Travellers. Trans. Nigel Spencer. Vancouver: Ronsdale Press, 2000.

Blais, Marie-Claire. David Sterne. Montréal: Éditions du jour, 1967.

Blais, Marie-Claire. Une saison dans la vie d'Emmanuel. Montréal: Éditions du Jour, 1965.

Castro, Azucena. “Approaching Photographic Ekphrasis”. International and interdisciplinary conference: Ekphrasis: From Paragone to Encounter. Hull, England: University of Hull, Department of English, 3-5 July, 2013.

Cheeke, Stephen. Writing for Art: The Aesthetics of Ekphrasis. Manchester: Manchester UP, 2009.

Croft, Stuart. Culture, Crisis and America's War on Terror. Cambridge: Cambridge UP, 2016.

Deleuze, Jacques and Félix Guattari. Kafka: Toward a Minor Literature. Trans. Dana Polan. Minnesota: U of Minnesota P, 1983.

Egan, Susanna and Gabriele Helms. "Autobiography and Changing Identities: Introduction". Biography 24.1 (Winter 2001): ix-xx.

Eppridge, Bill and Pete Hamill. A Time It Was: Bobby Kennedy in the Sixties. New York: Abrams, 2008. Heddon, Deirdre. Autobiography and Performance. Basingstoke: Palgrave Macmillan, 2008.

Heffernan, James A.W. Museum of Words: The Poetics of Ekphrasis from Homer to Ashbury. Chicago: Chicago UP, 1993.

LeBlanc, Julie. "Marie-Claire Blais's Transatlantic Literary Migrations in her Unpublished Notebooks, Short Story ("The Torment") and Novel (David Sterne)". Journal of the Short Story in English 61 (Spring 2013): 85-97.

LeBlanc, Julie. Genèses de soi: l'écriture du sujet féminin dans quelques journaux d'écriture. Montréal: Éditions du remue-ménage, 2008.

Luckhurst, Roger. “Introduction”. The Trauma Question. New York: Routledge, 2008.

Ricci, Franco. Painting with Words, Writing with Images. Toronto: U of Toronto P, 2001.

Robillard, Valerie and Els Jongeneel. "Introduction". Pictures into Words. Theoretical and Descriptive Approaches to Ekphrasis. Amsterdam: VU UP, 1998. 
Sontag, Susan. On Photography. New York: Penguin, 1979.

Wagner, Peter. Icons, Texts, Iconotexts: Essays on Ekphrasis and Intermediality. Berlin: Walter de Gruyter, 1996.

\section{NOTES}

1. In Autobiography and Performance, Deirdre Heddon uses the concept of "confessional times" to study the visual/performative aspect of autobiographical narratives.

2. "Le Tourment" is a short story published in 1988 (L'Atelier imaginaire, Lausanne: L'âge d'homme) and then reissued in 1992 in a collection of short stories entitled L'Exilé: nouvelles suivi de Les voyageurs sacrés (Montréal: Bibliothèque québécoise, 1992). The English edition of this collection of short stories, Exile and the Sacred Travellers, was translated by Nigel Spencer and published in Vancouver by Ronsdale Press in 2000. The story is entirely focused on the Vietnam War featuring a war veteran and pacifist.

3. Although my article will be almost entirely focussed on Passages américains (Montréal: Boréal, 2012), I will briefly reference fragments of her unpublished and illustrated notebooks written during the Vietnam War to accentuate how this historical event has truly haunted Marie-Claire Blais since the 1960s. It is also important to mention that although my attention will be focussed on one single essay published in Passages américains ("Lamentation pour un sénateur foudroyé" dedicated to Robert Kennedy's slaying), it is interesting that the other two essays are also focussed on violent acts which resulted in the murder of innocent victims, more notably Martin Luther King and the slaying of students at Kent State: "Désobéissances civiles" and "Les étudiants martyrs de l'Université Kent". The entire text is focused on various events related to the Vietnam War and the American political context of the 1960's. More than half of the essay is dedicated to Robert Kennedy and various violent and political events related to his life and assassination. The anti-war movements, John F. Kennedy and M. Luther King are also referenced throughout this essay.

4. Marie-Claire Blais's unpublished illustrated notebooks briefly referenced in my study were written between 1966 and 1968. They are mostly concerned with the Vietnam War and the conception of David Sterne, which was published with the Éditions du jour in 1967. My transcription, photograph and annotation of hundreds of pages of Marie-Claire's unpublished notebooks have allowed me to establish an extensive list of numerous diary entries where the Vietnam War is referenced. They are available in Fonds Marie-Claire Blais, National Library and Archives Canada, Ottawa.

5. Although the figure of ekphrasis will be described in more details when I turn to Passages americains, it is important to quote Peter Wagner in the introductory pages of my article as he stresses the complexity of even defining this ancient concept: "if critics agree at all about ekphrasis, they stress the fact that it has been variously defined and variously used and that the definition ultimately depends on the particular argument to be deployed [...]. Ekphrasis is a form of mimesis, it stages a paradoxical performance, promising to give voice to the allegedly silent image even while attempting to overcome the power of the image by transforming and inscribing it." Icons-Text-Iconotexts: Essays on Ekphrasis and Intermediality, 11-13. James Heffernan describes ekphrasis as "the verbal representation of visual representation" (Museum of Words, 7).

6. Since the object of my study is Passages américains. I have chosen to briefly reference Blais's notebooks in order to stress the importance of images of the Vietnam War in these unpublished illustrated diaries written during the 1960s and her more recently published essay in 2012. A detailed study of David Sterne, her novel written during the 1960s, and the genetic interest of her unpublished notebooks to the study of another novel written during that same decade (Une saison 
dans la vie d'Emmanuel) can be found in two different venues: Julie LeBlanc, "Marie-Claire Blais's Transatlantic Literary Migrations in her Unpublished Notebooks, Short Story ("The Torment") and Novel (David Sterne)", Journal of the Short Story in English, 61 (Spring 2013): 85-97; Julie LeBlanc, Genèses de soi: l'écriture du sujet féminin dans quelques journaux d'écriture, Montréal, Éditions du remue-ménage, 2008. Chapter 3 is dedicated to the unpublished notebooks and novel entitled Une saison dans la vie d'Emmanuel.

7. In his "Prologue" to A Time it was. Bobby Kennedy in the Sixties, Eppridge describes the form of photojournalism that he practiced during his career: "photographers as journalists are on a different wavelength than reporters and writers. We are still journalists, but from another viewpoint. Reporters list, photographers too. If you are doing your job seriously as a photojournalist your sight must be the primary sense that you use at all times" (25).

8. J.A.W. Heffernan's description of ekphrasis so often quoted by theorists (Museum of Words, 3).

9. As Eppridge explains: "Forty years ago, in 1968, I photographed a great tragedy, and the vision of it has stayed with me for all this time. Our country was going off course, with a war overseas, racial inequality, and far too much poverty in relation to the amount of wealth that existed. A man emerged to leas us out of this: Robert F. Kennedy. [...]. He died too young, too tragically, and this book is a photographic essay of that brief, euphoric time in our history" (25).

10. A. Castro, international and interdisciplinary conference: "Ekphrasis: From Paragon to Encounter" Hull, England: University of Hull, Department of English, 3-5 July, 2013, 1-5.

11. This is a fragment of Robert Kennedy's famous speech on the execution referenced in Blais's essay: "[...] Whatever the outcome of these battles, it is the people we seek to defend who are the greatest losers. Nor does it serve the interests of America to fight this war as if its moral standards could be subordinated to immediate necessities. Last week, a Vietcong suspect was turned over to the chief of the Vietnamese Security Services, who executed him on the spot-a violation of the Geneva Convention on the Rules of War. The photograph of the execution was on front pages all around the world-leading our best and oldest friends to ask, more in sorrow than in anger, what has happened to America?" Robert Kennedy, "Unwinnable War Speech," Chicago, February 08, 1968. Article accessed on this website: www.historyandtheheadlines. ABC-CLIO, 2011.

12. In A Time it Was: Bobby Kennedy in the Sixties, references are also made to these other iconic photos: "Then, at the end of January, news came about the Tet Offensive. The CommunistsNorth Vietnamese and Viet Cong from the south-had risen everywhere in South Vietnam, including Saigon. The great Eddie Adams photograph of General Nguyen Ngoc Loan shooting a Viet Cong suspect in the head on a Saigon street would appear everywhere in the world [...]" (14). This image is reproduced in Time: The Illustrated History of the World's Most Influential Magazine by Norberto Angeletti and Alberto Oliva, Rizzoli, 2010.

\section{ABSTRACTS}

What "testimonial culture" is part of and related to is a more general memory boom, itself indebted to the "transformation of the personal into the political". Inspired by Egan's treatment of various forms of testimonials, my article will be focused on Marie-Claire Blais's political testimonials, more importantly the textual representations of wars and the social and political crisis which they gave rise to during the $20^{\text {th }}$ and $21^{\text {st }}$ centuries. Through her textual and pictorial reflections on war found in her unpublished illustrated notebooks/diaries (1965-1970), novel ( 
David Sterne, 1967), short story ("Le Tourment", 1988), essays (Passages américains, 2012) and autobiographical narrative (Des rencontres humaines, 2002), which span more than five decades, Blais has become a performative witness to past tragic sociopolitical events which have haunted her since the 1960s: World War II, the Holocaust, the Vietnam War, the murder of American political figures (J.F. Kennedy, Dr. Martin Luther King and Robert Kennedy). My study is situated at the intersection of several major trends in the field of genetic criticism (study of manuscripts), theories of autobiography, word and image studies and various literary theories. Using an interdisciplinary perspective, my research is focused on studying the textual and visual strategies exploited by Blais to narrate her subjective experiences and to illustrate and perform her personal and collective memories dominated by a series of political crises.

Ce que Suzanna Egan appelle la « culture de témoignages » se rapporte à la conceptualisation que nous offre Paul Ricoeur de la mémoire (individuelle et collective), qui est elle-même redevable à la «transformation du personnel en politique ». Inspiré par cette définition que nous offre Egan, mon étude vise à exploiter les témoignages politiques de Marie-Claire Blais, notamment ses convictions sociopolitiques sur la guerre et les réactions qu'elles ont suscitées au cours des $\mathrm{XX}^{\mathrm{e}}$ et $\mathrm{XXI}^{\mathrm{e}}$ siècles. Grâce à ses réflexions textuelles et picturales sur la guerre, retrouvées dans ses carnets illustrés inédits (1965-1970), dans son roman David Sterne (1967), dans sa nouvelle «Le Tourment » (1988) et dans ses essais Passages américains (2012) qui ont été rédigés pendant plus de cinq décennies, Blais nous offre un riche témoignage de nombreux événements sociopolitiques qui l'ont accablée depuis les années soixante : la Seconde Guerre mondiale, la Shoah, la Guerre du Vietnam, l'assassinat de figures politiques américaines (J.F Kennedy, Dr. Martin Luther King et Robert Kennedy). Mon étude est située à la croisée de plusieurs domaines de recherche: la critique génétique, les théories de l'autobiographie, la sémiotique visuelle et la sociocritique. Mon but est de cerner les stratégies textuelles et visuelles exploitées par Blais pour exprimer, au sein de ses carnets illustrés inédits, de ses essais et de ses textes de fiction, ses réactions personnelles et convictions sociopolitiques face à de nombreux événements traumatiques: la Guerre du Vietnam et autres tragédies humaines issues de guerres sur le plan international.

\section{INDEX}

Keywords: genetic criticism, trauma, Vietnam War, photography, painting, ekphrasis, violence, murder, politics, portrait

Mots-clés: critique génétique, trauma, guerre du Vietnam, photographie, peinture, ekphrasis, violence, meurtre, politique, portrait

\section{AUTHORS}

\section{JULIE LEBLANC}

Julie LeBlanc is a Full-Professor in the Department of French and the Centre for Comparative Literature at the University of Toronto where she has taught since 1994. Her research interests lie in the areas of autobiographical narratives, word and image theories, genetic criticism, literary and cultural theories. She is the author of several theoretical and critical books which reflect her interests in interdisciplinary studies: Genèses de soi: l'écriture du sujet féminin dans quelques journaux d'écrivaines (2008); Énonciation et inscription du sujet: textes et avant-textes de Gilbert La Rocque (2000); Les Masques de Gilbert La Rocque (1999); Narrativité et iconicité au féminin (forthcoming 2018). She is presently working on a book: Genèse des rapports texte/image dans l'écriture autobiographique d'écrivains et d'artistes contemporains. She has also edited several 
thematic issues: Texte. Revue de critique et de théorie littéraire. "L'autobiographique", vol. 30/40; "Narrativité et iconicité", vol. 21-22; Voix et images, "Le Laboratoire de l'écriture: manuscrits et variantes", vol. 86; Recherches sémiotiques/Semiotic Inquiry RS/SI, "Rhétorique et sémiotique", vol. 12, no 3; Arborescences "Le Dispositif texte/image", vol. 6. She has also co-edited other thematic issues dedicated to theories of autobiography, feminist autobiographical narratives and discursive analysis. She has held numerous Federal Research Grants from SSHRC: Social Sciences and Humanities Research Council of Canada. 